\title{
Mass Foliar Damage at Subalpine-Timberline Ecotone in Western Himalaya Due to Extreme Climatic Events
}

\author{
Ishwari Datt Rai ${ }^{1}$, Bhupendra Singh Adhikari ${ }^{{ }^{*}}$, Gopal Singh Rawat ${ }^{1,2}$ \\ ${ }^{1}$ Department of Habitat Ecology, Wildlife Institute of India, Dehradun, India \\ ${ }^{2}$ Ecosystem Services, International Centre for Integrated Mountain Development, Kathmandu, Nepal \\ Email: *adhikaribs@wii.gov.in
}

Received April 10, 2012; revised May 11, 2012; accepted May 21, 2012

\begin{abstract}
Glimpses of unusual climatic conditions such as high summer temperature, heavy rainfall as well as snowfall and low winter temperature were noticed during 2010-2011 in subalpine-timberline (2700 - 3600 m) zones of Western Himalaya. Abundant winter injury to the current year (2010) foliage and shoot of Rhododendron arboreum and Quercus semecarpifolia became apparent in winters of 2010-2011. The foliar and bud mortality both increased with elevation beyond $2800 \mathrm{~m}$ and maximum along the edges of forest. Rhododendron campanulatum was another species which also got affected throughout the Western Himalaya. Such events were not reported earlier from the region and current observations indicate the high sensitivity of the plant species to the extreme inter-annual climatic variations.
\end{abstract}

Keywords: Foliar Damage; Extreme Climate; Western Himalaya

\section{Introduction}

Inferences of global warming for changes in extreme climatic events are of major concern for ecosystem functioning and human health [1]. Though, extreme events are rare in occurrence, sometimes have the most impacts on the forest health. Similar to the frequency of occurrence, only limited observational data are available for these extreme events worldwide. The global climate change is predicted to increase level of weather extremes and variability, and high altitude ecosystems are particularly sensitive [2]. The spring time and autumn temperature, duration of growth period, snowfall and melting patterns, and extreme climatic events viz., hailstorms, frost are of particular importance [3] for affecting adaptability of plant species. In many parts of the globe effects on the plant communities due to global warming such as boundary shift in timberlines [4,5], advances in phenological patterns [6-8], extended growing period [9], pathogens and insect infestation on forests $[10,11]$ were more frequent in recent past. Erratic climatic conditions exert a remarkable effect on plant communities and extremeness of an event for particular community depends on its rarity and the deviation from the normal conditions [12]. A drop in air temperature below a critical level leads to the mechanical damage of the species, which affects phenology of a particular species and dependency of other species on it.

\footnotetext{
"Corresponding author.
}

\section{Material and Methods}

\subsection{Study Area}

The intensive study carried out in Tungnath area of Kedarnath Wildlife Sanctuary (hereafter referred as KWS) between $30^{\circ} 29^{\prime}-30^{\circ} 30^{\prime} \mathrm{N}, 79^{\circ} 12^{\prime}-79^{\circ} 13^{\prime} \mathrm{E}$ along an elevational gradient from $2800-3400 \mathrm{~m}$ asl (above sea level) in Uttarakhand, Western Himalaya (Figure 1). The study area falls under the subalpine zone, which gives way to vast alpine meadows beyond the timberline ecotone. The preponderance of Betula utilis and Abies spectabilis on north facing slopes and Quercus semecarpifolia and Rhododendron arboreum on south facing slopes is the characteristic feature of the subalpine forests with some other associated species viz., Acer caesium, Prunus cornuta, Taxus wallichiana and Sorbus foliolosa. The krummholz formation by $R$. campanulatum dominates the shrub layer. The climate of the region has short dry summer (May-June) period followed by rainy season (July-September) with abundant relative humidity, and long winters having low temperatures with snow covered soil surface for about 3 - 4 months [12].

\subsection{Method}

Since 2007, phenological monitoring of major timberline tree species (B. utilis, Q. semecarpifolia, A. spectabilis, $R$. arboreum and R. campanulatum) was carried out in KWS, Western Himalaya with special reference to inter-annual 


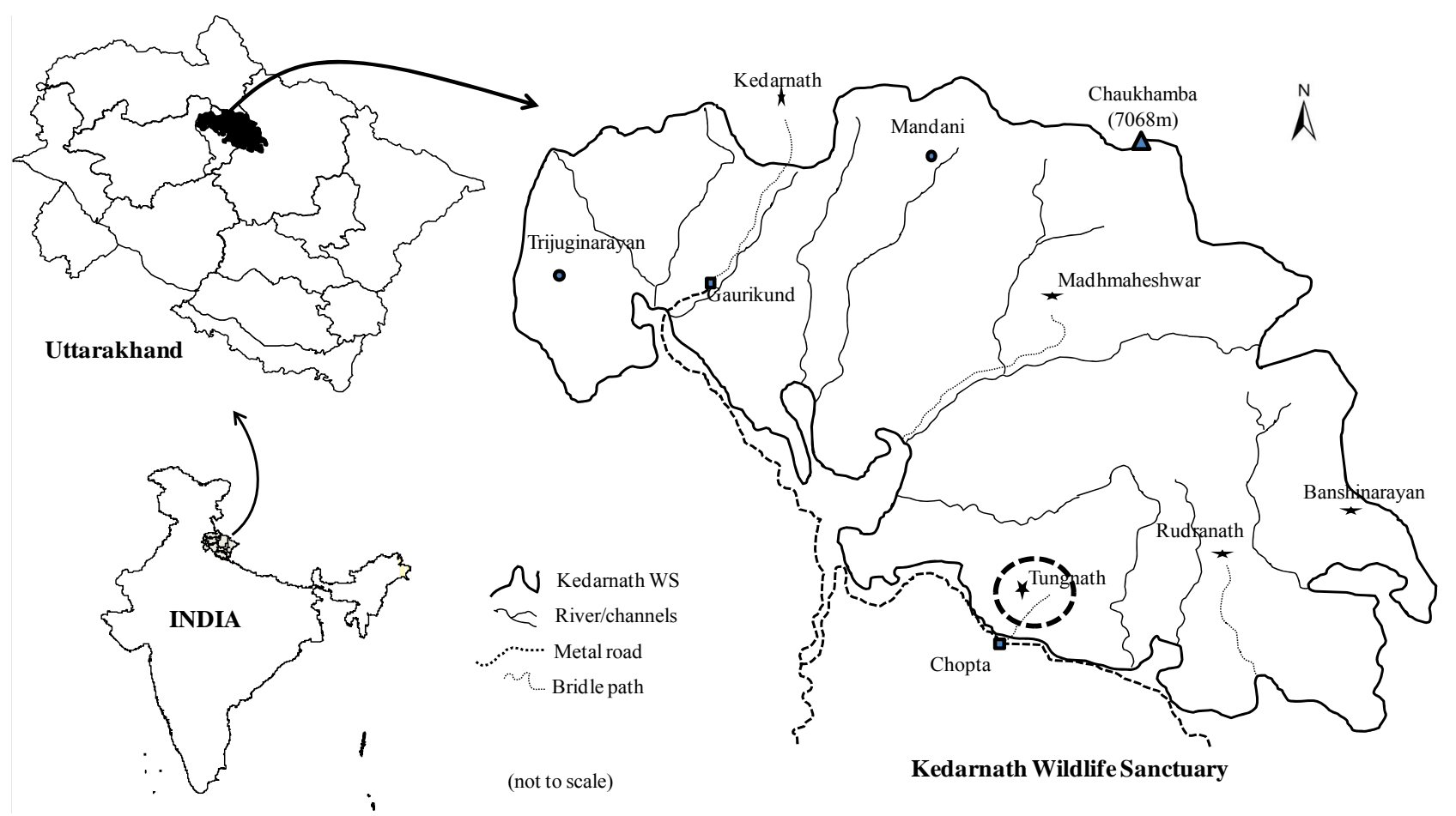

Figure 1. Map showing location of intensive study site (dotted circle) in KWS.

climatic variations. The patterns of the leaf emergence and leaf fall were also studied for various species in the region. The observation on foliar damage resulted after a continuous monitoring of the phenological events in these species.

The foliar damage was observed intensely in $Q$. semecarpifolia and $R$. arboreum across the subalpine-timberline zones. To quantify intensity of foliar damage in these species along the elevational gradient (3000 - 3300 $\mathrm{m})$, three sites were selected and in each site 20 individuals of each species were randomly selected. In each individual 5 twigs were randomly selected and total leaves along with damaged leaves were counted to quantify intensity of damage percent. It was observed that the total growing period $\left(>5^{\circ} \mathrm{C}\right.$ mean air temperature and initiation of bud swelling to maximum elongation of stem) was longest in 2010 for all the tree species in these three years. The sudden drop in mean air temperature was observed after the prolonged rainy season.

\section{Results and Discussion}

The winters of 2010-2011 received more snow with prolonged snow cover (December-April) and melting was later than the previous winters (all three years), so the extended period of snow cover with low air temperature is supposed to be one of the causes of the increased winter desiccation. The patterns of snow cover duration (winter season) at the timberline ecotone $(3300 \mathrm{~m})$ was 95, 65, 67 and 112 days, while the total cumulative depth of fresh snowfall was $171,140,166$ and $358 \mathrm{~cm}$, respectively for last four years (2007-2008 to 2010-2011). March-April months in year 2010 have comparatively higher temperature than that of last two years [12] and tree species have longer growth period along the subalpine to timberline ecotone due to moisture availability after snowmelt and higher temperature. The delayed monsoon towards the end of growing period in the month of September also extended the growth period.

In climatically favourable years, a longer and warmer growing season could also alter the hardening process of these species. Although, tree species are adapted for the climatic conditions at this elevational zone, extreme climatic events and sharp variation in the inter-annual climatic conditions may lead to change in their resistance and adaptability, as well as strategies during the growth period [1]. The sudden fall in temperature after rainy season may have resulted in the incomplete maturation of the tissues in leaves and shoots, which were affected the most, and consequently death of tissues occurred due to low temperature in winter months.

Quercus semecarpifolia is a dominant species in the region, which forms extensive forests in subalpine and timberline ecotone region and covers $\geq 34 \%$ land area in KWS between $3000-4000 \mathrm{~m}$ [12]. The damage was noticed highest $(47 \%)$ around timberline zone $(3300 \mathrm{~m}$; Figure 2) in the form of death of last year's shoot as well as leaves (Figure 3(a)). Another tree species, Rhododendron arboreum has the widest range of distribution 


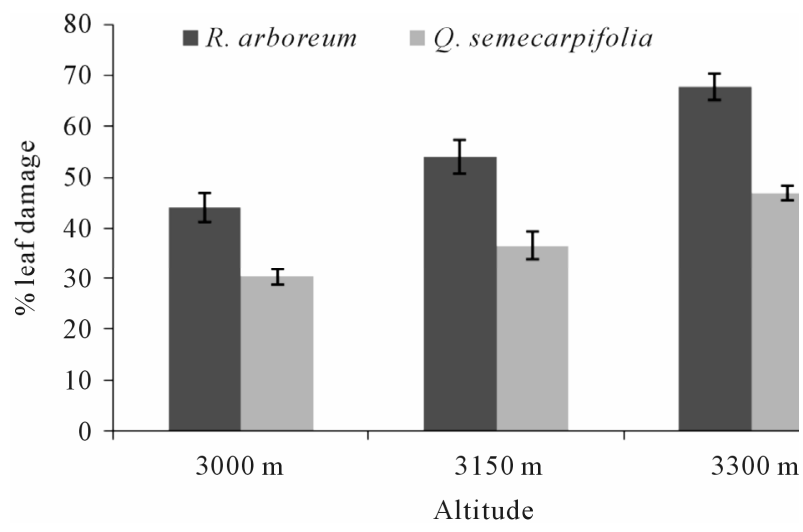

Figure 2. The intensity of foliar damage $( \pm \mathrm{SD})$ in Rhododendron arboreum and Quercus semecarpifolia along the altitudinal gradient in the study area.

along the altitudinal gradient (1400 - $3700 \mathrm{~m})$. The foliar damage was observed initially only in a few individuals in exposed areas (at the forest edges), which was accelerated after December 2010. The damage intensity in $R$. arboreum ranged between $44 \%(3000 \mathrm{~m})$ and $68 \%$ (3300 $\mathrm{m}$; Figure 2) and was the most affected species in the region. It was observed that the exposed individuals along the edges of forest gaps or timberline ecotone were highly affected, as the abaxial surface of leaves was dried and cuticle $(25 \%$ to $80 \%)$ layer was peeled off. The mortality was observed frequently in the isolated individuals around the timberline ecotone (Figure 3(b)).

At the timberline ecotone region, infolding of leaves of $R$. campanulatum is a common phenomenon to prevent winter damage, which become functional on the onset of favourable temperature after snowmelt. It is observed that several krummholz [13] patches of $R$. campanulatum around timberline ecotone and beyond were completely dried out and unable to revive in its normal condition in the year 2011. At the highest elevation of its distribution in the region $(3600 \mathrm{~m})$, not a single flowering bud was preceded to flowering stage and all the flower buds were damaged entirely.

In subalpine-timberline ecotone zones, mechanical damage in winters has conventionally been considered to be the result of desiccation stress [13]. The observed conditions indicate that species are more prone for damage due to the extreme events than steady inter-annual variations in the climate. The extreme climatic events tend to be much more important to initiate change in forest ecosystems than average climatic conditions $[1,14,15]$. The evergreen broadleaved species were affected more as compared to deciduous or needle bearing coniferous species. Studies related to the winter damage had prevalence of the coniferous species $[13,16,17]$, whereas in the present observation conifers (Abies and Taxus) were found least affected. Being a broadleaved and evergreen species, $Q$. semecarpifolia, $R$. arboreum and $R$. campanulatum
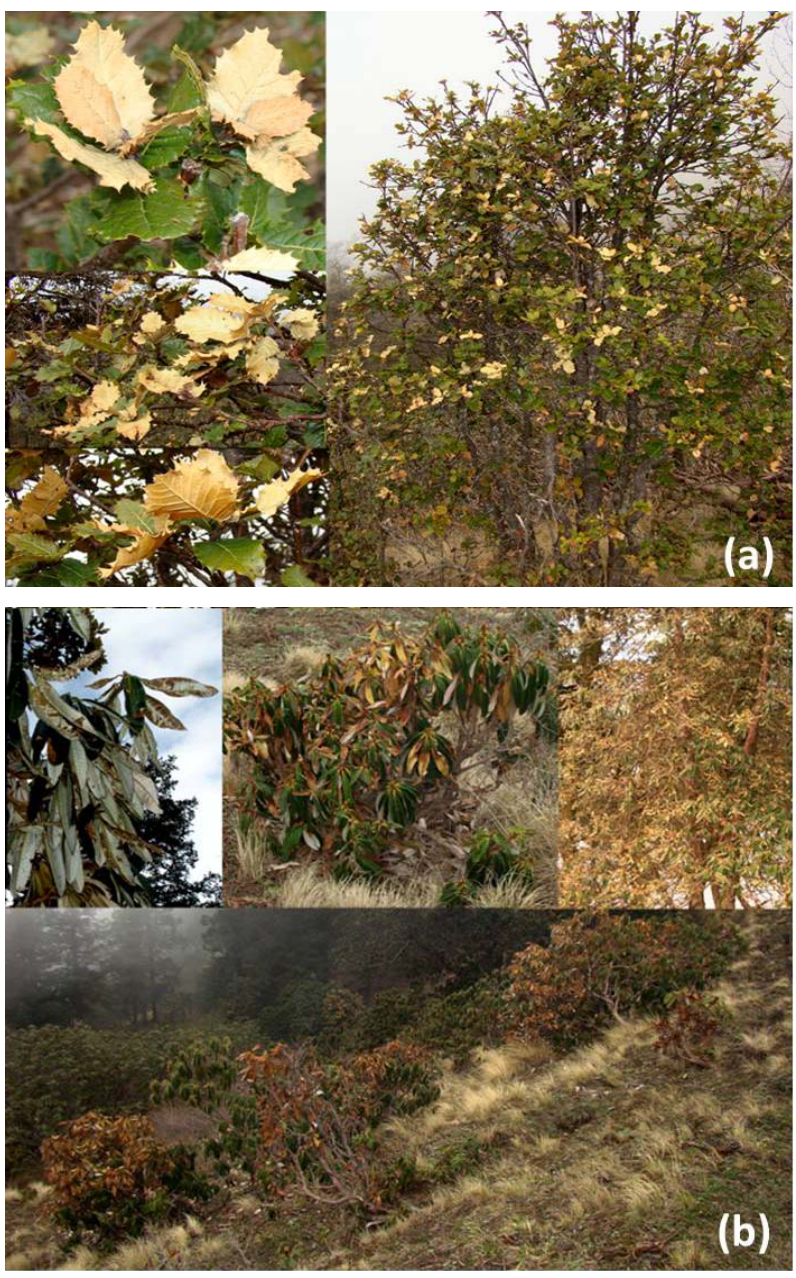

Figure 3. Foliar damage in Quercus semecarpifolia; dried twig and leaves and tree (a); and foliar damage and mortality in Rhododendron arboreum at timberline ecotone (b).

may affect most due to extreme climatic condition and sudden change in the temperature. Though, these events are for a rather short period, they have much impact on the evergreen broadleaved species by reducing their productivity, as the evergreen broadleaved species have greater nutrient extraction efficiency as compared to conifers [18], will have to compete with conifers as well as deciduous species for the resources in the event of foliar damage. The high altitude fauna (Himalayan monal, Musk deer, Asiatic black bear) are highly dependent on these species in the region, as these species are major source of food and shelter for them and along the timberline ecotone many plant species (Cypripedium spp., Balanophora involucrata, Skimmia anquetilia) survive under their canopies. These extreme events change the phenology of plants, which further affects the synchronized phenology of faunal species too.

The data on snowfall, snow-cover duration and winter temperature is rarely available for the high altitude regions of Western Himalaya and such events on winter 
damage are never documented. It is most important to track the intensity and frequency of these extreme climatic event to predict impacts of changing climate on the timberline region of high altitude landscape, which is supposed to be more vulnerable to climate change [19].

\section{Acknowledgements}

Authors are thankful to Director and Dean, Wildlife Institute of India, Dehradun for providing necessary facilities and Uttarakhand Forest Department for granting permission for work.

\section{REFERENCES}

[1] M. Beniston, H. F. Diaz and R. S. Bradley, "Climate Change at High Elevation Sites," Climate Change, Vol. 36, No. 3-4, 1997, pp. 233-251.

[2] J. A. Patz, D. Campbell-Lendrum, T. Holloway and J. A. Foley, "Impact of Regional Climate Change on Human Health," Nature, Vol. 438, No. 7066, 2005, pp. 310-317. doi:10.1038/nature04188

[3] P. Forst, J. Caban and P. Michahk, "Protection of Forests and Environment," Statnizemidilskenakladatelstvi, Praha, 1985.

[4] P. Wardle and M. C. Coleman, "Evidence for Rising Upper Limits of 4 Native New Zealand Forest Trees," New Zealand Journal of Botany, Vol. 30, No. 3, 1992, pp. 303314. doi:10.1080/0028825X.1992.10412909

[5] L. Kullman, "20th Century Climate Warming and Tree Limit Rise in the Southern Scandes of Sweden," Ambio, Vol. 30, No. 2, 2001, pp. 72-80.

[6] D. R. Cayan, S. A. Kammerdiener, M. D. Dettinger, J. M. Caprio and D. H. Peterson, "Changes in the Onset of Spring in the Western United States," Bulletin of the American Meteorological Society, Vol. 82, No. 3, 2001, pp. 399-415.

doi:10.1175/1520-0477(2001)082<0399:CITOOS $>2.3$.C $\mathrm{O} ; 2$

[7] R. Ahas, A. Aasa, A. Menzel, V. G. Fedotova and H. Scheifinger, "Changes in European Spring Phenology," International Journal of Climatology, Vol. 22, No. 14, 2002, pp. 1727-1738. doi:10.1002/joc.818

[8] T. H. Sparks, B. Jaroszewicz, K. M. Marta and P. Tryja- nowski, "Advancing Phenology in Europe's Last Lowland Primeval Forest: Non-Linear Temperature Response," Climate Research, Vol. 39, No. 3, 2009, pp. 221-226. doi: $10.3354 / \mathrm{cr} 00812$

[9] A. Menzel and P. Fabian, "Growing Season Extended in Europe," Nature, Vol. 397, No. 6721, 1999, p. 659. doi:10.1038/17709

[10] B. E. Lazarus, P. G. Schaberg, D. H. DeHayes and G. J. Hawley, "Severe Red Spruce Winter Injury in 2003 Creates Unusual Ecological Event in the Northeastern United States," Canadian Journal of Forestry Research, Vol. 34, No. 8, 2004, pp. 1784-1788.

[11] S. K. Uniyal and A. Uniyal, "Climate Change and LargeScale Degradation of Spruce: Common Pattern across the Globe," Climate Research, Vol. 38, No. 3, 2009, pp. 261 263. doi: $10.3354 / \mathrm{cr} 00792$

[12] B. S. Adhikari, G. S. Rawat, I. D. Rai, S. Bhattacharyya and R. R. Bharti," Ecological Assessment of Timberline Ecotone in Western Himalaya with Special Reference to Climate Change and Anthropogenic Pressures," IV Annual Report, Wildlife Institute of India, Dehradun, 2011.

[13] W. Tranquillini, "Physiological Ecology of the Alpine Timberlines," Springer-Verlag, Berlin, 1979. doi:10.1007/978-3-642-67107-4

[14] R. W. Katz and B. G. Brown, "Extreme Events in a Changing Climate: Variability Is More Important than Averages," Climate Change, Vol. 21, No. 3, 1992, pp. 289-302.

[15] J. L. Innes, "The Impacts of Climatic Extremes on Forests: An Introduction," In: M. Beniston and J. L. Innes, Eds., The Impacts of Climatic Variability on Forests, SpringerBerlag, Berlin, 1998, pp. 1-18.

[16] J. L. Hadley and W. K. Smith, "Wind Effect on Needles of Timberline Conifers: Seasonal Influence on Mortality," Ecology, Vol. 67, No. 1, 1986, pp. 12-19.

[17] A. Sakai and W. Larcher, "Frost Survival of Plants: Responses and Adaptation to Freezing Stress," SpringerVerlag, Berlin, 1987.

[18] B. S. Adhikari, Y. S. Rawat and S. P. Singh, "Structure and Function of High Altitude Forests of Central Himalaya II. Nutrient Dynamics," Annals of Botany, Vol. 75, No. 3, 1995, pp. 249-258. doi:10.1006/anbo.1995.1018

[19] IPCC, "Climate Change 2007: The Physical Science Basis," Cambridge University Press, Cambridge, 2007. 